\title{
KEBUTUHAN TENAGA PENGAWAS SMK DI KOTA TERNATE
}

\author{
Yanto Yusuf ${ }^{1}$, Rustam Hasim ${ }^{2}$ \\ ${ }^{1}$ Guru PPKn SMAN 3 Kota Ternate \\ ${ }^{2}$ Dosen Program studi Pendidikan Pancasila dan Kewarganegaraan FKIP Unkhair
}

Email: yantoyusuf@gmail.com; hasyimrustam7@gmail.com

$\begin{array}{ll}\text { Diterima } & : 20-02-2019 \\ \text { Direvisi } & : 30-03-2019 \\ \text { Dipublikasi } & : 01-05-2019\end{array}$

\begin{abstract}
Abstrak. Penelitian ini mendeskripsikan bagaimana manajemen supervisi pengawas dalam meningkatkan kualitas guru dan siswa pada pelaksanaan pembelajaran di lingkungan Dinas Pendidikan Nasional Kota Ternate. Selain itu juga dilihat dari kinerja pengawas dalam peningkatan mutu pendidikan di lingkungan Dinas Pendidikan Nasional Kota Ternate dan pelaksanaannya dalam mengelola sumber daya pendidikan di sekolah. Penelitian ini menggunakan pendekatan kualitatif naturalistik untuk menggambarkan pengawas SMK pada Dinas Kota Ternate secara alami, lengkap, mendalam, dan utuh. Pendekatan kualitatif naturalistik digunakan untuk memperoleh informasi dan penafsiran mendalam mengenai makna manajemen sumberdaya manusia sesuai dengan realitas yang ada di lapangan. Teknik Pengumpulan data dalam penelitian ini dilakukan melalui beberapa teknik, yaitu pengamatan, wawancara, dan dokumentasi. Teknik pengumpulan data secara wawancara digunakan untuk menjawab pertanyaan penelitian yang telah disediakan. Informan terdiri dari kepala dinas pendidikan, pengawas, kepala sekolah, guru dan komite sekolah. Hasil penelitian ini menunjukkan bahwa rekruitmen tenaga pengawas Dinas Pendidikan Kota Ternate belum optimal dalam melihat aspek pemerataan penempatan guru, administrasi, pengelolaan, pengembangan, pengawasan, dan pelayanan teknis untuk menunjang proses pendidikan pada satuan pendidikan. Di samping itu, masih terdapat kesenjangan pengawas mata pelajaran di setiap sekolah. Selain itu masih banyak tenaga pendidik belum maksimal dalam melaksanakan kewajiban sebagai guru yang profesional.
\end{abstract}

Kata Kunci: Pengawas, tenaga pendidik, dan Dinas Pendidikan Kota Ternate

\section{PENDAHULUAN}

Dalam pendidikan, pengawasan merupakan bagian tidak terpisahkan dalam upaya peningkatan prestasi belajar dan mutu sekolah (Imron, 2011). Usaha meningkatkan kompetensi guru dan kepala sekolah dapat dilakukan dengan memberikan bantuan profesional dalam bentuk penyelenggaraan, konsultasi dan bimbingan, serta kegiatan yang berkaitan dengan peningkatan kualitas kompetensi lainnya. Salah satu peran penting pengawas adalah mengubah kebiasaan melakukan perubahan yang kosmetis dan artifisal menjadi perubahan yang substantif dan bermakna bagi dunia pendidikan secara keseluruhan, bukan sekedar perubahan formalistis.Tarikan-tarikan pragmatisme yang membawa pada formalisme perubahan oleh pengawas diarahkan untuk menjadi perubahan substantif, sehingga proses perubahan pendidikan di tanah air menjadi bermutu (Imron, 2011; Maunah \& others, 2008).

Pengawasan dalam pendidikan bertujuan mengembangkan potensi peserta didik melalui kegiatan belajar mengajar bermutu yang dilayani guru (Imron, 2011). Pengawasan berkaitan dengan pengakuan dan pengharagaan atas diri anak sebagai manusia yang utuh yang harus dihargai dan dihormati, bukan pengawasan seperti pada proses produksi barang. Peningkatan kualitas pendidikan bukanlah tugas yang ringan bagi seorang pengawas karena tidak hanya berkaitan dengan permasalahan teknis, tetapi mencakup berbagai persoalan yang sangat rumit dan kompleks, baik yang menyangkut perencanaan, pendanaan, maupun efisiensi dan efektivitas penyelenggaraan sistem sekolah. Peningkatan kualitas pendidikan juga menuntut manajemen sumber daya manusia (SDM) yang mempunyai fungsi perencanaan, rekruitmen dan seleksi, manajemen pendidikan yang lebih baik (Imron, 2011; Sabandi, 2013). 
Pengawas sekolah benar-benar memahami dan menerapkan kompetensi pengawas sekolah yang tercantum di Permendiknas No. 12 Tahun 2007, maka dapat dipastikan kecil kemungkinan akan terjadi hal-hal yang tidak diinginkan, yakni ada nada miring mengenai pengawas sekolah di lapangan (Ngalim, 2002). Keberadaan pengawas sekolah sebagai ujung tombak pengawal kebijakan Dinas Pendidikan melalui sebuah Renstra (Rencana dan Strategi) sudah didesain dalam kurun waktu lima tahun untuk memberikan pemahaman terhadap peningkatan mutu di sekolah (Sabandi, 2013).

Undang-Undang Republik Indonesia Nomor 14 tahun 2005 tentang guru pada pasal: 1 ayat 1 menyebutkan guru adalah pendidik profesional dengan tugas utama mendidik, mengajar, membimbing, mengarahkan, melatih, menilai, dan mengevaluasi peserta didik pada anak usia dini jalur pendidikan formal, pendidikan dasar, dan pendidikan menengah. Pada pasal: 2 ayat 1 guru mempunyai kedudukan sebagai tenaga profesional pada jenjang pendidikan dasar, pendidikan menengah, dan pendidikan usia dini pada jalur pendidikan formal yang diangkat sesuai dengan peraturan perundang-undangan. Pada ayat 3, yang dimaksud profesional adalah pekerjaan atau kegiatan yang dilakukan oleh seseorang dan menjadi sumber penghasilan kehidupan yang memerlukan keahlian, atau kecakapan, yang memenuhi standar mutu atau norma tertentu serta memerlukan pendidikan profesi.

Menyadari betapa pentingnya peningkatan kualitas pendidikan, pemerintah Kota Ternate telah melakukan berbagai upaya, termasuk diantaranya mengeluarkan Surat Keputusan Walikota dalam rangka menata sistem perencanaan tentang rincian tugas pada Dinas Pendidikan Nasional Kota Ternate meliputi: susunan organisasi, kepala dinas, bagian tata usaha, bagian umum, bagian kepegawaian, bagian perencanaan dan evaluasi, sub dinas pendidikan dasar dan taman kanak-kanak, sub dinas menegah, umum, dan kejuruan, cabang-cabang dinas dan unit pelaksanaan teknis diknas, sehingga diharapkan program-program pendidikan yang dihasilkan oleh sistem perencanaan tersebut berhasil membawa masyarakat meraih tujuan pendidikan yang dicita-citakan (Rajaloa \& Hasim, 2018).

Keputusan Walikota Ternate tentang Rincian Tugas Pada Dinas Pendidikan Nasional Kota Ternate meliputi; susunan organisasi, kepala dinas, bagian tata usaha, bagian umum, bagian kepegawaian, bagian perencanaan dan evaluasi, sub dinas pendidikan dasar dan taman kanak-kanak, sub dinas menengah, umum, dan kejuruan, cabang-cabang dinas dan unit pelaksanaan teknis diknas. Untuk kelancaran tugas tersebut, maka mengacu pada keputusan Walikota Ternate Nomor 32 Tahun 2004 tentang Rincian Tugas Pada Dinas Pendidikan Nasional Kota Ternate dengan menimbang bahwa: Dalam rangka meningkatkan kelancaran pelaksanaan tugas dinas untuk sumber daya guna dan berhasil guna maka Pemerinta Kota Ternate perlu menindaklanjuti peraturan tersebut dengan melaksanakan pembentukan susunan organisasi dan Tata Kerja Diknas Pendidikan Nasional Kota Ternate mengingat; Peraturan Pemerintah Nomor 2000 Tentang Kewenangan Pemerintah dan Kewenangan Provinsi sebagai daerah Otonom; Peraturan Daerah Kota Ternate Nomor 22 Tahun 2000 tentang pembentukan, susunan organisasi dan tata kerja Dinas Pendidikan Nasional; Undang-Undang Republik Indonesia Nomor; 20 Tahun 2003 tentang Sistem Pendidikan Nasional; Undang-Undang Nomor; 32 tahun 2004 tentang pemerintah daerah; Undang-Undang Republik Indonesia Nomor; 14 Tahun 2005 tentang Guru dan Dosen.

Terwujudnya hasil pembangunan dalam rangka menuju Kota Ternate sebagai Kota Pendidikan yang Berkualitas, Pariwisata yang Berbudaya, Pertumbuhan dan Pelayanan Jasa yang Prima, Terciptanya masyarakat Madani dan Ramah Lingkungan yang oleh prinsip-prinsip partisipasi, penegakan hukum, transparansi, responsibilitas, konsensus/komitmen, keadilan, kredibilitas, efektif dan efisien, akuntabilitas dan mempunyai wawasan kedepan.

Sumber daya manusia yang berkemampuan memadai, perlu disusun suatu strategi yang tepat dalam berbagai aspek agar setiap sumber daya manusia yang ada di lingkungan Dinas Pendidikan Nasional Kota Ternate akan mampu mengemban kualitas sumber daya manusia merupakan isu yang perlu ditangani secara cepat oleh Dinas Pendidikan Nasional Kota Ternate agar unit kerja tersebut menjadi 
motor penggerak penyelenggaraan tugas pemerintah dan pembangunan di bidang pendidikan Kota Ternate.

\section{METODE PENELITIAN}

Penelitian ini menggunakan pendekatan kualitatif naturalistik untuk dapat menggambarkan secara alami, lengkap, mendalam dan utuh mengenai pokok persoalan. Pendekatan kualitatif yang digunakan dimkasudkan untuk memperoleh informasi dan penafsiran yang mendalam mengenai (efektifitas kinerja manajemen supervisi oleh pengawas dalam penyelenggaraan supervisi di sekolah), sesuai dengan realiats yang ada di lapangan, oleh karean itu pengumpulan data berdasarkan situasi yang wajar, langsung, dan apa adanya.

Lingkungan Dinas Pendidikan Nasional Kota Ternate merupakan tempat penelitian atas dasar pertimbangan antara lain dari segi kualitas, lokasi, dan persentasi para pengawas di Dinas Pendidikan Nasional Kota Ternate. Dari 6 orang pengawas yang berprestasi, maka 1 yang dipilih sebagai subjek penelitian. Pengawas tersebut mendapat penghargaan dari Menteri Pendidikan Nasional sebagai pengawas berprestasi. Penelitian ini dilaksanakan pada bulan Januari hingga April 2013.

\section{Teknik Pengumpulan Data}

Norman Denzin \& Vonna Lincoln (2010: 18-19), bahwa peneliti memiliki beberapa metode pengumpulan data yang meliputi; (1) Dokumentasi. Dokumentasi adalah suatu teknik pengumpulan data melalui bahan-bahan tertulis yang berkaitan dengan masalah penelitian. Peneliti memegang catatan harian, sejarah kehidupan cerita, biografi, peraturan, kebijakan, dan dokumen yang berbentuk gambar misalnya, foto, gambar hidup, sketsa, untuk mencatat hal-hal yang bersifat bebas atau belum ditentukan dalam daftar peneliti. Menurut (Sugiyono, 2012) dokumen merupakan catatan peristiwa yang sudah berlalu; (2) Observasi. Dalam penelitian ini peneliti mengobservasi tentang supervisi yang dilakukan pengawas sekolah dalam melakukan supervisi kelas, dalam meningkatkan profesionalisme dan kualitas guru dalam proses pembelajaran; (3) Wawancara. Wawancara adalah percakapan dengan maksud tertentu. Percakapan itu dilakukan oleh dua pihak, yaitu pewawancara (interviewer) yang mengajukan pertanyaan dan terwawancara (respondent) yang memberikan jawaban atas pertanyaan itu. Hamid Darmadi (2011:158) wawancara adalah pengadministrasian angket secara lisan dan langsung terhadap masing-masing anggota sampel.

Dalam penelitian ini dilakukan wawancara secara bebas dan terkontrol, artinya wawancara dilakukan secara bebas sehingga diperoleh data yang luas dan mendalam. Wawancara yang digunakan peneliti berbentuk wawancara semi struktur dengan alasan agar peneliti bebas dan leluasa dalam mengajukan pertanyaan-pertanyaan tanpa terkait oleh suatu susunan pertanyaan-pertanyaan yang telah disiapkan sebelumnya. Menurut (Sugiyono, 2012), wawancara semistruktur sudah termasuk dalam kategori indepth interview, dimana dalam pelaksanaannya lebih bebas dibandingkan dengan wawancara terstruktur. Dengan wawancara terstruktur, pihak yang diajak wawancara lebih terbuka mengemukakan pendapat dan ide-idenya.

Sementara teknik analisa data lebih banyak dilakukan bersamaan dengan pengumpulan data.Untuk mengecek keabsahan data maka dilakukan beberapa hal. Menurut Miles \& Huberman (1992: 16) menyatakan cakupan penelitian dalam empat alur kegiatan yang secara bersamaan, yaitu: pengumpulan data, reduksi data, penyajian data, penarikan kesimpulan/verifikasi. Analisa data yang akan dilakukan peneliti berproses sejak merumuskan dan menjelaskan masalah, sebelum terjun ke lapangan, terjun kelapangan hingga penulisan hasil penelitian. Analisa data menurut Janice McDrury (Collaborative Group Analysis of Data, 1999) dalam Lexy J. Moleong, 2012:248) bahwa peneliti harus mempelajari data mengemukakan proses, dan komponen-komponen yang ada dalam satu analisa data berupa katakata kunci, model agar sumber datanya tetap dapat ditelusuri. 


\section{PEMBAHASAN}

\section{Kriteria Khusus Yang Harus dipenuhi Seorang Pengawas}

Pengawas sekolah ialah pegawai negeri sipil (PNS) yang diberi tugas, tanggung jawab, dan wewenang secara penuh oleh pejabat yang berwenang untuk melakukan pengawasan pendidikan disekolah dengan melaksanakan penilaian dan pembinaan segi teknis pendidikan, adminstrasi pada satuan pendidikan prasekolah, dasar, dan menengah (Aqib \& Rohmanto, 2007). Instansi pembina jabatan fungsional pengawas adalah Depdiknas.

Kualifikasi akademik yang dijelaskan di atas dijadikan dasar dalam melaksanakan rekruitmen dan seleksi calon pengawas. Artinya dalam pengangkatan pengawas satuan pendidikan rekruitmen atau penjaringan calon pengawas harus memenuhi kualifikasi tersebut di atas untuk selanjutnya mengikuti seleksi atau penyaringan secara khusus.

Kualifikasi akademik yang dipersyaratkan bagi pengawas dan calon pengawas satuan pendidikan terdiri atas kualifikasi umum dan khusus.

(1) Umum (berlaku untuk semua pengawas satuan pendidikan):

a) Memiliki pangkat minimal Penata golongan ruang III/c

b) Berusia maksimal 50 tahun sejak diangkat sebagai pengawas satuan pendidikan.

c) Pernah menyandang predikat guru atau kepala sekolah berprestasi

d) Lulus seleksi pengawas satuan pendidikan

e) Menempuh pendidikan profesi pengawas

(2) Umum (berlaku untuk semua pengawas satuan pendidikan):

Seleksi melalui tes yang terdiri atas tes tertulis, tes performance dan forto folio. Tes tertulis meliputi (1) tes potensi akademik dan kecerdasan emosional; (2) tes penguasaan kepengawasan; dan (3) tes kreativitas dan motivasi berprestasi. Tes performance dilaksanakan melalui presentasi makalah kepengawasan dilanjutkan dengan wawancara. Sedangkan forto folio dilaksanakan melalui penilaian terhadap karya-karya tulis ilmiah yang dihasilkan calon pengawas serta bukti fisik keterlibatan dalam kegiatan ilmiah seperti seminar, workshop, pelatihan dll.

Memberikan sebuah kontrol adalah upaya pengawas sekolah agar sesuatu proses pendidikan yang dilaksanakan di sekolah lebih baik dari pada hasil yang dicapai sebelumnya atau berupa saran kepada Kepala Sekolah untuk menindaklanjuti pembinaan yang tidak dapat dilaksanakan sendiri. Kepala Sekolah merupakan pucuk pimpinan dari suatu satuan pendidikan yang dengan kepemimpinannya diharapkan dapat memajukan sekolah (Aqib \& Rohmanto, 2007).

Untuk melaksanakan tugas pokok tersebut, pengawas sekolah melaksanakan fungsi supervisi, baik supervisi akademik maupun supervisi manajerial. Supervisi akademik adalah fungsi supervisi yang berkenaan dengan aspek pembinaan dan pengembangan kemampuan profesional guru dalam meningkatkan mutu pembelajaran dan bimbingan di sekolah.

Sementara itu ketika penulis bertanya tentang apakah persebaran tenaga pengawas di sekolah sudah sesuai dengan kebutuhan sekolah/masyarakat? Kepada Bapak Y. (Pengawas Dinas Pendidikan Nasional Kota Ternate) dalam hal ini mengatakan bahwa:

"Persebaran pengawas, sebetulnya pengawas itu ada 2 yaitu pertama pengawas akademik masih harus ada penyebaran pemeratan lagi, sedangkan pengawas satuan pendidikan sudah tidak ada masalah, dan ruang lingkup pengawas berada di Kota Ternate dan sudah ada pengawas masing-masing, contohnya ada pengawas di kecamatan Batang Dua, Pulau Moti dan Pulau Hiri serta pengawas korwas hanya ada satu, sekolah yang dikunjugi di awal tahun ajaran dan sudah ada jadwal kunjungan dan disahkan oleh korwas". 
Persebaran pengawas, sebetulnya pengawas itu ada dua yaitu pertama pengawas akademik masih harus ada penyebaran pemeratan lagi, sedangkan pengawas satuan pendidikan sudah tidak ada masalah, dan ruang lingkup pengawas berada di kota Ternate dan sudah ada pengawas masing-masing contohnya ada pengawas di kecamatan Batang Dua, Pulau Moti dan Pulau Hiri serta pengawas korwas hanya ada satu, sekolah yang dikunjugi di awal tahun ajaran dan sudah ada jadwal kunjungan dan disahkan oleh korwas. Pengawas yang juga merupakan mitra guru dalam meningkatkan mutu pendidikan berperan sangat penting kaitannya dengan tugas mengawasi kinerja guru. Dengan demikian diharapkan guru merasa diperhatikan dan diberikan solusi dalam pemecahan masalah untuk kemajuan proses belajar mengajar.

Dari penjelasan tersebut dapat disimpulkan bahwa tugas utama pengawas sekolah tersebut adalah menilai dan membina penyelenggaran pendidikan pada sejumlah sekolah tertentu, baik negeri maupun swasta yang menjadi tanggung jawabnya (Keputusan Bersama Mendiknas dan kepala BAKN, 1996). Supervisi akademik berkaitan dengan fungsi pembinaan, penilaian, perbantuan, dan pengembangan kemampuan guru dalam meningkatkan kualitas proses pembelajaran/bimbingan dan kualitas hasil belajar siswa. Sejalan dengan fungsi supervisi diatas.

Sasaran supervisi akademik antara lain membantu guru dalam hal; (1) merencanakan kegiatan pembelajaran dan atau bimbingan; (2) melaksanakan kegiatan pembelajaran/ bimbingan; (3) menilai proses dan hasil pembelajaran/ bimbingan; (4) memanfaatkan hasil penilaian untuk peningkatan layanan pembelajaran/bimbingan; (5) memberikan umpan balik secara tepat dan teratur dan terus menerus pada peserta didik; (6) melayani peserta didik yang mengalami kesulitan belajar; (7) memberikan bimbingan belajar pada peserta didik; (8) menciptakan lingkungan belajar yang menyenangkan; (9) mengembangkan dan memanfaatkan alat Bantu dan media pembelajaran dan atau bimbingan; (10) memanfaatkan sumber-sumber belajar; (11) mengembangkan interaksi pembelajaran/bimbingan (metode, strategi, teknik, model, pendekatan dll.) yang tepat dan berdaya guna; (12) melakukan penelitian praktis bagi perbaikan pembelajaran/bimbingan; dan (13) mengembangkan inovasi pembelajaran/bimbingan (Aqib \& Rohmanto, 2007).

Dalam menjalankan supervisi pendidikan yakni kepala sekolah sebagai supervisor berusaha untuk dapat menolong guru dan mengembangkan kurikulum. Menyediakan fasilitas yang memungkinkan guru-guru dapat menambah dan mempertinggi pengetahuan serta membina rasa kekeluargaan antara guru-guru dan pegawai sekolah sesuai dengan kondisi dan situasi setempat. Maju tidaknya pendidikan di suatu sekolah tergantung juga kepada kepala sekolah sebagai tenaga kependidikan, baik personal, sosial maupun professional harus benar-benar dipikirkan karena pada dasarnya kepala sekolah sebagai tenaga pendidikan disekolah menjadi contoh teladan bagi bawahannya serta kepada peserta didiknya dan sebagai ujung tombak keberhasilan pendidikan disekolah (Aqib \& Rohmanto, 2007; Hayun \& Hasyim, 2018).

Dengan demikian dapat disimpulkan bahwa tugas pokok yang pertama merujuk pada supervisi atau pengawasan manajerial sedangkan tugas pokok yang kedua merujuk pada supervisi atau pengawasan akademik. Pengawasan manajerial pada dasarnya memberikan pembinaan, penilaian dan bantuan / bimbingan mulai dari rencana program, proses, sampai dengan hasil. Bimbingan dan bantuan diberikan kepada kepala sekolah dan seluruh staf sekolah dalam pengelolaan sekolah atau penyelenggaraan pendidikan di sekolah untuk meningkatkan kinerja sekolah. Pengawasan akademik berkaitan dengan membina dan membantu guru dalam meningkatkan kualitas proses pembelajaran/bimbingan dan kualitas hasil belajar siswa.

Sedangkan wewenang yang diberikan kepada pengawas sekolah meliputi; (1) memilih dan menentukan metode kerja untuk mencapai hasil yang optimal dalam melaksanakan tugas dengan sebaik-baiknya sesuai dengan kode etik profesi; (2) menetapkan tingkat kinerja guru dan tenaga lainnya yang diawasi beserta faktor-faktor yang mempengaruhinya; dan (3) menentukan atau mengusulkan program pembinaan serta melakukan pembinaan. Wewenang tersebut menyiratkan adanya otonomi pengawas 
untuk menentukan langkah dan strategi dalam menentukan prosedur kerja kepengawasan. Namun demikian pengawas perlu berkolaborasi dengan kepala sekolah dan guru agar dalam melaksanakan tugasnya sejalan dengan arah pengembangan sekolah yang telah ditetapkan kepala sekolah (Aqib \& Rohmanto, 2007; Imron, 2011; Sabandi, 2013).

Mengacu pada SK Menpan nomor 118 tahun 1996 tentang jabatan fungsional pengawas dan angka kreditnya, Keputusan bersama Mendikbud nomor 03420/O/1996 dan Kepala Badan Administrasi Kepegawaian Negara nomor 38 tahun 1996 tentang petunjuk pelaksanaan jabatan fungsional pengawas serta Keputusan Mendikbud nomor 020/U/1998 tentang petunjuk teknis pelaksanaan jabatan fungsional pengawas sekolah dan angka kreditnya, dapat dikemukakan tentang tugas pokok dan tanggung jawab pengawas sekolah yang meliputi:

1. Melaksanakan pengawasan penyelenggaraan pendidikan di sekolah sesuai dengan penugasannya pada TK, SD, SLB, SLTP dan SLTA.

2. Meningkatkan kualitas proses belajar-mengajar/bimbingan dan hasil prestasi belajar/bimbingan siswa dalam rangka mencapai tujuan pendidikan.

\section{Pendistribusian Kebutuhan Tenaga Pengawas}

Ruang lingkup pembinaan mencakup pembinaan kualifikasi, profesi dan pembinaan karir. Pembinaan kualifikasi ditujukan agar para pengawas dapat meningkatkan tingkat pendidikan formal sampai minimal berpendidikan Sarjana (SI) bagi yang berpendidikan diploma, dan berpendidikan S2 bagi pengawas yang berpendidikan S1. Pengembangan profesi diarahkan pada peningkatan kompetensi pengawas mencakup kompetensi pribadi, kompetensi sosial, kompetensi pedagogik dan kompetensi professional. Sedangkan pembinaan karir pengawas diarahkan untuk mempercepat kenaikan pangkat dan jabatan pengawas sesuai dengan ketentuan yang berlaku melalui pengumpulan angka kredit. Jenjang jabatan pengawas mulai dari pengawas pratama sampai pada pengawas utama.

Program pembinaan sumberdaya manusia pendidik oleh Dinas Pendidikan Kota Ternate meliputi; program diklat para guru pada setiap jenjang pendidikan (SD, SMP dan SMA). Peningkatan proses pendidikan dilakukan melalui pembinaan kepribadian, sikap, dan kemampuan teknis profesionalisme guru dilakukan melalui penataran dan pemanfaatan wadah Kelompok Kerja Guru, Kelompok Guru Mata Pelajaran, Kelompok Kerja Kepala Sekolah, Dan Kelompok Kerja Pengawas Sekolah. Pembinaan mutu guru juga dilakukan program penyetaraan Guru Sekolah Dasar (PGSD). Bertujuan meningkatkan mutu lulusan Sekolah Dasar melalui peningkatan pendidikan guru minimal pada jenjang Diploma Dua (D-II). Pembinaan mutu guru juga dilakukan melalui promosi jabatan guru. Promosi jabatan meliputi jabatan inti, guru pemandu bidang studi, kepala sekolah maupun pengawas sekolah. Promosi juga memperhatikan sikap dan kepribadian dalam melaksanakan tugas yang meliputi kegiatan guru dimasyarakat, organisasi sosial dan keagamaan, kepramukaan, maupun kepengurusan dalam PGRI. Program pembinaan guru dilakukan melalui penataran-penataran yang berkaitan dengan seluruh bidang studi diajarkan di sekolah (Hasyim \& Yusuf, 2017).

Sejalan dengan itu, pembinaan kemampuan profesional pengawas satuan pendidikan bertujuan untuk meningkatkan kompetensi pengawas baik kompetensi pribadi, kompetensi sosial, kompetensi pedagogik maupun kompetensi profesional. Dengan meningkatnya kompetensi pengawas diharapkan terjadi peningkatan kinerjanya sehingga berdampak terhadap mutu pendidikan pada satuan pendidikan yang dibinanya. Pembinaan diberikan kepada para pengawas satuan pendidikan untuk semua kategori jabatan pengawas yakni pengawas pratama, pengawas muda, pengawas madya dan pengawas utama. Menurut S.P (Kepala Sekolah SMK Negeri 5 Kota Ternate) mengatakan bahwa:

"Kami dari pihak sekolah dalam hal memberikan pelayanan sebagai ikhtiar ketika ada kunjungan pengawas itu secara otomatis wakasek kurikulum dan kepala sekolah sudah mempunyai ikhtiar. Yang dimaksud dengan ikhtiar adalah kapan pengawas akan turun, kami dari sekolah sudah siap tapi kadang ada hal yang diluar sepengtahuan kami misalnya persiapan-persiapan awal itu tidak pernah disyaratkan kepada kami sehingga kadang ada hal- 
hal yang kami tidak sadari adan harus ada disiapkan karena mungkin ada hal-hal yang sifatnya dadakan, tapi yang pasti kami dari pihak sekolah selalu ikhtiar dan siaga terhadap kondisi, karena pengawas kadang memberikan informasi tentang kedatangannya, kadang juga tidak memberikan informasi jadi sifatnya inspeksi dadakan (Sidak) itu selalu dilakukan. Ini yang kami maksud sebagai ikhtiar kepada kami di sekolah-sekolah"(Wawancara 18 Pebuari 2013).

Pengawas utama selain mengarahkan tugas-tugas pokok pengawas satuan pendidikan yang menjadi bimbingannya juga memberikan penilaian terhadap kemajuan dan prestasi pengawas yang didampinginya. Kelebihan dan kekurangan pengawas bimbingannya didiskusikan dan dipecahkan bersama-sama. Pengawas pratama dan pengawas muda dilatih dan dimbimbing membuat program kerja kepengawasan, metode dan tehnik melaksanakan program pengawasan serta menilai keberhasilan tugas kepengawasan. Program pendampingan ini mirip dengan program magang yang selama ini dilaksanakan.

Sebagai tenaga profesional, guru dituntut meningkatkan profesionalisme dengan melalui belajar sendiri maupun melalui program pembinaan dan pengembangan yang telah ditetapkan oleh Dinas Pendidikan. Berdasarkan hasil penelitian bahwa peningkatan profesionalisme guru di Kota Ternate dilakukan melalui kegiatan seminar, pelatihan, dan pendidikan. Pembinaan profesi guru meliputi pembinaan kompetensi pedagogik, kompetensi kepribadian, kompetensi profesional, dan kompetensi sosial. Upaya yang dapat dilakukan guru untuk meningkatkan kompetensinya adalah berpartisipasi dalam forum atau kegiatan ilmiah seperti; membuat karya tulis ilmiah, karya seni, dan karya teknologi, melaksanakan penelitian/pengkajian kerja profesionalnya baik secara individual maupun kelompok (Hasyim \& Yusuf, 2017).

Pengawas sekolah mempelajari situasi guru akan tampil bagaiman keadan kelas, keadan siswa, kelengkapan sarana pembelajaran kemajuan siswa terutama mata pelajaran yang di kunjungi. Pengawas tidak boleh mencari kesalahan-kesalahan guru, tetapi dimana pengawas itu harus membimbing, dimana kekurangan guru, kesalahan kita zaman sekarang ini pengawas tidak ada mencari-cari kesalahan guru, kalau memang pengawas itu diangkat berdasarkan kriteria. Belum alasannya mungkin yang tadi saya katakan harusnya idealnya perbidang studi baru yang aktif misalnya Bahasa Inggris, pengawas produktif, kalau untuk menyurat ke dinas itu belum, tetapi biasanya ada supervisi dari dinas. Dari kegiatan supervisi tersebut ada rapat evaluasi, untuk disampaikan.

Upaya yang dapat dilakukan Dinas Pendidikan Kota Ternate dalam membina dan mengembangkan kemampuan profesional pengawas dapat dilakukan dengan memfasilitasi pengawas untuk berpartisipasi dalam kegiatan seminar, lokakarya, diskusi panel, simposisum dan kegiatan ilmiah lainnya. Kegiatan ilmiah tersebut dapat diselenggarakan baik oleh pihak luar misalnya: Perguruan Tinggi, Pemda, Organisasi Profesi, dan pihak terkait lainnya, maupun yang diselenggarakan oleh pihak Dinas Pendidikan itu sendiri. Tema seminar terutama yang membahas berbagai masalah tentang pendidikan dan atau tugas-tugas kepengawasan. Kegiatan ilmiah ini akan bermanfaat bagi pengawas dalam meningkatkan pengetahuan dan wawasan baru tentang pendidikan dan kepengawasan, agar mereka tidak ketinggalan dengan inovasi-inovasi pendidikan yang sedang berlangsung. Hal yang sama mengikutsertakan dan memfasilitasi pengawas untuk mengikuti kegiatan penataran dan lokakarya yang diselengarakan bagi guru dan atau kepala sekolah. Melalui kegiatan ini wawasan pengawas tidak ketinggalan oleh guru dan kepala sekolah. Manfaat lain dari kegiatan ini adalah diperolehnya penghargaan berupa sertifikat yang dapat digunakan untuk pengumpulan angka kredit jabatan fungsional. Tugas pokok pengawas adalah melaksanakan pengawasan akademik meliputi pembinaan, pemantuan pelaksanaan Standar Nasional Pendidikan pada sejumlah SLB di kabupaten/kota

\section{Mekanisme Pengakatan Pengawas Kota Ternate}

Pengawas sekolah ialah pegawai negeri sipil (PNS) yang diberi tugas, tanggung jawab, dan wewenang secara penuh oleh pejabat yang berwenang untuk melakukan pengawasan pendidikan disekolah dengan melaksanakan penilaian dan pembinaan segi teknis pendidikan, adminstrasi pada satuan pendidikan 
prasekolah, dasar, dan menengah. Instansi pembina jabatan fungsional pengawas adalah Depdiknas (Hasyim \& Yusuf, 2017).

Tugas pokok pengawas mata pelajaran atau kelompok mata pelajaran yaitu melaksanakan pengawasan akademik meliputi pembinaan, pemantauan pelaksanaan Standar Nasional Pendidikan (standar isi, standar proses, standar penilaian, standar kompetensi lulusan) pada guru mata pelajaran di sejumlah satuan pendidikan yang ditetapkan.

Kegiatan supervisi kegiatan manajerial meliputi pembinaan dan pemantauan pelaksanaan manajemen sekolah merupakan kegiatan dimana terjadi interaksi langsung antara pengawas satuan pendidikan dengan kepala sekolah dan tenaga kependidikan lainnya. Kegiatan ini dilaksanakan di sekolah binaan. Pelaksanaan pembinaan dengan menggunakan format dan instrumen yang ditentukan oleh dinas pendidikan di kabupaten/kota bersangkutan.

Kegiatan supervisi pemantauan meliputi pemantauan dan pembinaan pelaksanaan SNP merupakan kegiatan dimana terjadi interaksi langsung antara pengawas satuan pendidikan dengan kepala sekolah dan tenaga kependidikan lainnya. Kegiatan ini dilaksanakan di sekolah binaan. Pelaksanaan pembinaan dengan menggunakan format dan instrumen yang ditentukan oleh dinas. Kehadiran pengawas itu bukan memantau siswa secara langsung, bagaimana kehadiranya itu mengsupervisi guru yang bersangkutan pada saat mengajar sehingga posisi pengawas itu pada saat dikelas menyesuaikan sama seperti siswa jadi pengawas yang datang bukan pengawas yang otoriter tetapi pengawas berbaur dengan siswa bagaimana memantau cara mengajar guru sehingga terserapan siswa itu dapat tercapai. Biasanya sebelum turun ada penyampaian dari pengawas tapi semacam jadwal itu dalam bentuk supervisi biasanya menyurat, tapi dalam bentuk supervisi setiap mata pelajarankan kan ada supervisi gabungan, ada supervisi mata-mata pelajaran bisanya berkordinasi dengan kepala sekolah terus kepala sekolah mengarakan berkoridinasi langsung dengan guru mata pelajaran yang bersangkutan (Maunah \& others, 2008; Ngalim, 2002).

Pengawas sekolah selalu melaksanakan tugas supervisi manajemen sekolah dan melakukan kerja sama dengan masyarakat sekitar. Pendidikan merupakan tanggung jawab bersama antara keluarga masyarakat dan pemerintah. Sehingga orang tua tidak boleh menganggap bahwa pendidikan anak hanyalah tanggung jawab sekolah. Pendidikan merupakan suatu usaha manusia untuk membina kepribadiannya agar sesuai dengan norma-norma atau aturan di dalam masyaratakat. Setiap orang dewasa di dalam masyarakat dapat menjadi pendidik, sebab pendidik merupkan suatu perbuatan sosial yang mendasar untuk petumbuhan atau perkembangan anak didik menjadi manusia yang mampu berpikir dewasa dan bijak (Yusuf \& Hasyim, 2016).

Bagi kelancaran dan keefektivan obeservasi, supervisor hendaknya memiliki suatu pedoman observasi yang harus direncanakan sebelum observasi dilaksanakan. Karena observasi di sini sebagai teknik pengawasan, maka supervisor harus menetapkan:

1. Apa yang harus diobservasi atau diawasi.

2. Kriteria-kriteria yang dijadikan tolak ukur pertimbanga pengawasannya; dan sebagainya Untuk memudahkan pengolahan data, maka sebaiknya pedoman observasi menggunakan skala penilaian, antara laian: Skala angka (numerical scale), skala grafik (graphic scale), skala grafik deskriptif (descriptive graphic scale) atau kartu nilai (score card).

\section{Pengawas Jarang Mengunjungi Sekolah Binaannya}

Setiap pengawas membuat laporan dalam bentuk laporan per sekolah dari seluruh sekolah binaan. Laporan ini lebih ditekankan kepada pencapaian tujuan dari setiap butir kegiatan pengawasan sekolah yang telah dilaksanakan pada setiap sekolah binaan. Penyusunan laporan oleh pengawas merupakan upaya untuk mengkomunikasikan hasil kegiatan atau keterlaksanaan program yang telah direncanakan.Menyusun laporan pelaksanaan program pengawasan dilakukan oleh setiap pengawas 
dengan segera setelah melaksanakan pembinaan, pemantauan atau penilaian.Wawancara dengan ketua komite SMK pembangunan kota Ternate mengatakan:

"Bahwa guru-guru yang dibina tersebut, biasanya datang begitu saja, datang begitu sering mara- bahwa Selama ini yang saya lihat pengawas datang sekolah binaan tidak karena setau saya mulai ada pengawas kami sampai sekarang tidak memberikan pelajaran tambahan kepada mara setelah itu pulang dan langsung dan pergi”. (Wawancara 4 April 2013).

Kegiatan pembimbingan dan pelatihan profesionalitas guru dilaksanakan paling sedikit 3 (tiga) kali dalam satu semester secara berkelompok di MGMP atau KKG. Kegiatan ini dilaksanakan terjadwal baik waktu maupun jumlah jam yang diperlukan untuk setiap kegiatan sesuai dengan tema atau jenis keterampilan dan kompetensi yang akan ditingkatkan. Dalam pelatihan ini diperkenalkan kepada guru cara-cara baru yang lebih sesuai dalam melaksanakan suatu proses pembelajaran/ pembimbinan. Kegiatan pembimbingan dan pelatihan profesionalitas guru ini dapat dilakukan melalui workshop, seminar, observasi, individual dan group conference, serta kunjungan kelas melalui supervisi akademik.

Program pengawasan semester adalah perencanaan teknis operasional kegiatan yang dilakukan oleh setiap pengawas mata pelajaran atau kelompok mata pelajaran pada setiap sekolah dimana guru binaannya berada. Program tersebut disusun sebagai penjabaran atas program pengawasan tahunan di tingkat kabupaten/kota. Kegiatan penyusunan program semester oleh setiap pengawas mata pelajaran ini diperkirakan berlangsung selama 1 (satu) minggu. Itulah salah satu hal yang kita lihat kadang kalah ada hal tertentu yang dibutukan oleh parah pengawas baru secara mendadak atau tiba-tiba baru pengawas muncul sehingga tidak ada istilahnya pembinaan, bimbingan terhadap guru yang ditugaskan oleh pengawas di sekolah, tersebut tidak ada bimbingan seperti itu. Sebelum pengawas itu datang apakah secara dadakan atau sudah rencanakan diberitahukan dari awal itu jauh-jauh tempo kami sudah sampaikan kepada siswa kita harus selalu siap mental jika suatu saat ada hal-hal tertentu atau mendapat kunjungan dari pihak dinas kota atau diknas provinsi itu kita siap kadang mereka turun langsung dalam kelas jadi kita harus siap sebelum mereka turun jadi hal itu kami sudah sampaikan sehingga pengawas itu datang mereka tidak kaget lagi.

Program pengawasan semester adalah perencanaan teknis operasional kegiatan yang dilakukan oleh setiap pengawas sekolah pada setiap sekolah binaannya. Program tersebut disusun sebagai penjabaran atas program pengawasan tahunan di tingkat kabupaten/kota. Kegiatan penyusunan program semester oleh setiap pengawas satuan pendidikan ini diperkirakan berlangsung selama 1 (satu) minggu. Kegiatan supervisi bimbingan dan konseling meliputi pembinaan dan pemantauan pelaksanaan bimbingan dan konseling di sekolah merupakan kegiatan dimana terjadi interaksi langsung antara pengawas dengan guru binaanya. Melaksanakan penilaian adalah menilai kinerja guru dalam merencanakan, melaksanakan dan menilai proses pembimbingan. Kegiatan ini dilakukan di sekolah binaan, sesuai dengan uraian kegiatan dan jadwal yang tercantum dalam RKBK yang telah disusun. Oleh karena itu, tujuan pendidikan adalah untuk memajukan budi pekerti sehingga seorang individu menjadi manusia yang berbudi pekerti luhur dan mampu mencapai kesempurnaan hidup sehingga mampu hidup selaras dengan alam dan masyarakatnya. Namun mengapa perilaku membuang sampah sembarangan, membuang limbah tanpa pengolahan terlebih dahulu, eksploitasi hasil hutan, eksploitasi hasil tambang, dan perilaku yang mengeksploitasi dan merusak alam lainnya masih sering kita dengar, lihat dan rasakan di negara kita (Yusuf \& Hasyim, 2016).

\section{Penetapan dan Pembagian Kebutuhan Pengawas dalam Mengsupervisi}

Tugas pokok pengawas satuan pendidikan adalah melakukan pengawasan manajerial terdiri dari pembinaan, pemantauan (standar pengelolaan, standar pembiayaan, standar sarana dan prasarana, standar pendidik \& tenaga kependidikan) dan penilaian kinerja sekolah pada satuan pendidikan yangmenjadi binaannya. 
Tugas pengawas satuan pendidikan meliputi penyusunan program pengawasan satuan pendidikan, melaksanakan pembinaan, pemantauan dan penilaian, menyusun laporan pelaksanaan program pengawasan.Wawancara dengan R.J.T (guru SMK Negeri 3 Kota Ternate) mengatakan bahwa:

"Pengawas sekolah merencanakan jadwal supervisi kelas biasanya di awal tahun ajaran. Sesudah itu, pengawas sudah datang ke sekolah dengan membawa jadwal dari Diknas. Biasanya di jadwal tersebut dipaparkan perencanan kunjugan yang pertama pada bulan keberapa, minggu keberapa kedua, dan ketiga itu sudah dijadwalkan dan ditempel di ruang guru dan semua guru juga sudah tahu jadwal pengawas. Tentu saja ada administrasinya, absen, buku batas, program tahunan, program semester, kalender akademik, RPP, Silabus, jadwal masuk kelas, absen siswa dan daftar nilai itu sudah menjadi satu” (Wawancara 27 Maret 2013).

Setiap pengawas membuat laporan dalam bentuk laporan per sekolah dari seluruh sekolah binaan. Laporan ini lebih ditekankan kepada pencapaian tujuan dari setiap butir kegiatan pengawasan sekolah yang telah dilaksanakan pada setiap sekolah binaan. Penyusunan laporan oleh pengawas merupakan upaya untuk mengkomunikasikan hasil kegiatan atau keterlaksanaan program yang telah direncanakan.

Setiap pengawas membuat laporan dalam bentuk laporan per sekolah dari seluruh sekolah binaan. Laporan ini lebih ditekankan kepada pencapaian tujuan dari setiap butir kegiatan pengawasan sekolah yang telah dilaksanakan pada setiap sekolah binaan. Penyusunan laporan oleh pengawas merupakan untuk mengkomunikasikan hasil kegiatan atau keterlaksanaan program yang telah direncanakan. Menyusun laporan pelaksanaan program pengawasan dilakukan oleh setiap pengawas sekolah dengan segera setelah melaksanakan pembinaan, pemantauan atau penilaian. Wawancara dengan Wakasek SMK Negeri 3 Kota Ternate), mengatakan bahwa:

"Bagaimana kita ketahui selama ini menyangkut dengan tenaga pengawas yang ditugaskan disetiap sekolah, sekolah binaannya, menyangkut dengan pengangkatan atau penempatan pengawas di sekolah binaan ini selama ini yang saya tahu adalah kewenangan dari Dinas Pendidikan Nasional jadi ketika mereka telah di-SK-kan sebagai pengawas dan diberikan hak tugas dan tanggung jawab dimana sekolah binaan mereka masing-masing setelah mereka datang di sekolah baru kita tahu bahwa dengan SK yang diberikan oleh walikota, baru mereka datang disekolah baru kita tahu, bahwa pengawas kita si A, B, C. Tapi yang menyangkut dengan pengangkatan pada saat itu kita tidak dilibatkan/sekolah tidak tahu. Kita (pihak sekolah) tahu setelah mereka melaksanakan tugas dengan didasarkan atas Surat Keputusan bahwa mereka diangkat sebagai pengawas dan mereka (pengawas-pengawas itu) merupakan pengawas binaan sekolah masing-masing”.(Wawancara 26 Maret 2013).

Dari jawaban responden di atas, bahwa kegiatan Pengawas satuan pendidikan, pengawas mata pelajaran, dan pengawas bimbingan dan konseling belum dapat memenuhi ketentuan karena kurangnya jumlah satuan pendidikan atau guru yang dibina. Hal ini dapat dipenuhi kekurangannya dengan ketentuan sebagai berikut; (1) Mendapatkan tugas tambahan menjadi pengawas satuan pendidikan pada jenjang yang berbeda, misalkan pengawas TK merangkap menjadi pengawas SMK; (2) Mendapatkan tugas tambahan bukan kepengawasan dari kepala dinas pendidikan. Jenis tugas tambahan tersebut merupakan sebagian tugas rutin pada dinas pendidikan; (3) Khusus bagi pengawas satuan pendidikan yang berkedudukan di Provinsi dapat melaksanakan kewajiban 24 (dua puluh empat) tatap muka di sekolah binaan yang ditetapkan oleh Dinas Pendidikan Provinsi untuk satu kabupaten/kota atau lebih. Pemenuhan jumlah tatap muka pengawas dikoordinasikan oleh Kepala Dinas Pendidikan Provinsi dengan Dinas Pendidikan Kota Ternate.

\section{KESIMPULAN}

Bab terakhir dalam penelitian ini secara garis besar berisi kesimpulan dari hasil pembahasan dan saran yang dapat diberikan berkenaan dengan penelitian yang telah dilakukan. Kesimpulan dari dua bagian 
penting dalam menjawab pertanyaan penelitian. Berdasarkan analis data tersebut dapat ditarik sebagai berikut:

1. Dari hasil penelitian yang dilakukan terhadap sejumlah pengawas di Kota Ternate ternyata manajemen supervisi oleh Pengawas di Lingkungan Dinas Pendidikan Nasional Kota Ternate dalam rangka meningkatkan kemampuan profesionalnya boleh dikatakan belum berjalan sebagaimana mestinya. Pengawas sekolah berjalan apa adanya dengan tugas pokok dan fungsinya melakukan pengawasan dengan berbekal kemampuan yang telah dimilikinya. Pengawas juga membuat laporan kepada Kepala Dinas Pendidikan tentang apa yang telah dilakukannya sesuai dengan tupoksinya namun laporan tersebut belum dijadikan dasar bagi upaya pembinaan para pengawas. Kalaupun ada, pembinaan terbatas pada arahan dan penjelasan Kepala Dinas Pendidikan Kota Ternate tentang berbagai kebijakan pendidikan dalam rapat-rapat khusus dengan para pengawas dan pejabat lainnya. Pembinaan para pengawas yang dilaksanakan secara terencana dan bersinambungan yang mengarah pada kemampuan profesional para pengawas dan pengembangan karirnya sebagai tenaga fungsional belum banyak dilaksanakan. Lemahnya pembinaan para pengawas diduga berkaitan dengan sumberdaya yang terbatas pada setiap dinas pendidikan, baik sumber daya manusia, sumber daya keuangan maupun sumber daya informasi. Selain itu komitmen dinas pendidikan terhadap pentingnya peran pengawas dalam meningkatkan mutu pendidikan terkesan kurang optimal, sehingga program pembinaan bagi para pengawas belum menjadi prioritas. Pada sisi lain, hasil kerja yang dicapai para pengawas dari pelaksanaan tugas pokok dan fungsinya belum begitu signifikan terhadap kemajuan-kemajuan sekolah binaannya. Oleh karena itu, posisi, peran dan eksisteni pengawas kurang mendapat perhatian dibandingkan dengan guru dan kepala sekolah.

3. Dari hasil penelitian dan temuan di lapangan menunjukkan bahwa terjadi kesenjangan peran pengawas. Pengawas sekolah belum melaksanakan perannya secara maksimal sebagai supervisor, advising, monitoring, sebagai reporting, coordinating, dan performing leadership sesuai dengan tupoksi pengawas. Temuan-temuan tersebut dapat dijelaskan sebagai berikut:

\section{a. Supervisor}

Dalam melaksanakan fungsi supervisi, pengawas hendaknya berperan sebagai:

1) Mitra guru dalam meningkatkan mutu proses dan hasil pembelajaran dan bimbingan di sekolah binaannya

2) Inovator dan pelopor dalam mengembangkan inovasi pembelajaran dan bimbingan di sekolah binaannya

3) Konsultan pendidikan di sekolah binaannya

4) Konselor bagi kepala sekolah, guru dan seluruh staf sekolah

5) Motivator untuk meningkatkan kinerja semua staf sekolah

\section{b. Advising}

Dalam melaksanakan fungsi supervisi, pengawas hendaknya berperan sebagai: Pemberi arahan, bantuan dan bimbingan kepada guru tentang proses pembelajaran/bimbingan yang bermutu untuk meningkatkan mutu proses dan hasil belajar/ bimbingan siswa.

\section{c. Monitoring}

Pengawas sebagai pemantau mempunyai tiga peran, pertama sebagai pemantau perencanaan pendidikan di sekolah, kedua memantau proses pengambilan keputusan, ketiga memantau kualitas kebijakan program dan proses perencanaan pendidikan di sekolah.

\section{d. Reporting}

Peran sebagai reporting adalah melaporkan output pendidikan, melaporkan hasil ujian akhir, melaporkan angka partisipasi sekolah, melaporkan proses perencanaan pendidikan, penyusunan 
tehadap program sekolah yang harus dilaporkan kepada kepala dinas, masyarakat, dan sekolah itu sendiri.

\section{e. Coordinating}

Tugas mengkoordinir sumber-sumber daya sekolah baik sumber daya manusia, material, finansial dll, mengkoordinir kegiatan antar sekolah, mengkoordinir kegiatan preservice dan in-service training bagi Kepala Sekolah, guru dan staf sekolah lainnya, mengkoordinir personil stakeholder yang lain, mengkoordinir pelaksanaan kegiatan inovasi sekolah.

\section{f. Performing Leadership}

Memimpin pengembangan kualitas SDM di sekolah binaannya, memimpin pengembangan inovasi sekolah, partisipasi dalam memimpin kegiatan manajerial pendidikan di Diknas yang bersangkutan, partisipasi pada perencanaan pendidikan di kabupaten/kota, partisipasi pada seleksi calon kepala sekolah/calon pengawas, partisipasi dalam akreditasi sekolah, partisipasi dalam merekrut personal untuk proyek atau program-program khusus Peranan pengawas pengembangan mutu sekolah, partisipasi dalam mengelola konflik di sekolah dengan win-win solution dan partisipasi dalam menangani pengaduan baik dari internal sekolah maupun dari masyarakat. Itu semua dilakukan guna mewujudkan kelima tugas pokok di atas.

3. Penempatan tugas pengawas satuan pendidikan menjadi tanggung jawab Kepala Dinas Pendidikan Kota Ternate dengan mempertimbangkan tipe dan kondisi geografis letak sekolah selaras dengan bidang dan jenjang jabatan pengawas. Selanjutnya pembinaan dan pengembangan pengawas satuan pendidikan dilaksanakan secara berkelanjutan agar kemampuan profesional serta karirnya sebagai pengawas satuan pendidikan meningkat sejalan dengan prestasi yang dicapainya. Dengan kata lain pembinaan dan pengembangan pengawas diarahkan untuk memelihara, mempertahankan serta mempertinggi kinerjanya sehingga berdampak pada peningkatan mutu sekolah binaannya. Pembinaan pengawas dimaksudkan sebagai upaya yang terencana dalam memelihara dan meningkatkan kemampuan profesi dan karirnya sehingga mempertinggi kinerjanya sebagai pengawas satuan pendidikan yang profesional.

\section{DAFTAR PUSTAKA}

Aqib, Z., \& Rohmanto, E. (2007). Membangun Profesionalisme Guru dan Pengawas Sekolah. In Bandung: Yrama Widya (Vol. $62)$.

Hasyim, R., \& Yusuf, M. (2017). Supervisi Pembelajaran Kepala Sekolah dalam Meningkatkan Kompetensi Guru IPS di SMPN 2 Kota Ternate. EDUKASI, 15(1), 630-642.

Hayun, S., \& Hasyim, R. (2018). MANAJEMEN KOMPETENSI GURU NEGERI OLEH DINAS PENDIDIKAN KABUPATEN HALMAHERA TIMUR. GeoCivic, 1(1), 14-25.

Imron, A. (2011). Supervisi Pembelajaran Tingkat Satuan Pendidikan. In Jakarta: Bumi Aksara.

Maunah, H. B., \& others. (2008). Supervisi Pendidikan (Teori dan Praktek) (Vol. 1). STAIN Tulungagung.

Ngalim, P. (2002). Administrasi dan Supervisi Pendidikan. In Bandung. PT Remaja Rosdakarya.

Rajaloa, N. I., \& Hasim, R. (2018). Manajemen Perencanaan dan Rekrutmen Tenaga Pendidik Oleh Dinas Pendidikan Kota Ternate. EDUKASI, 16(1), 11-28.

Sabandi, A. (2013). Supervisi Pendidikan Untuk Pengembangan Profesionalitas Guru Berkelanjutan. Pedagogi: Jurnal Ilmu Pendidikan, 13(2), 1-9.

Sugiyono. (2012). Metode Penelitian Kuantitatif, Kualitatif Dan R\&D. Bandung: Alfabeta, p. 361. https://doi.org/10.1017/CBO9781107415324.004 
Yusuf, M., \& Hasyim, R. (2016). Peranan Guru dalam Membangun Kesadaran Cinta Tanah Air Pada Siswa Sekolah Dasar (Telaah Teoritik). Pedagogik, 4(1), 8-16. 